\title{
Temporal and spatial responses of river discharge to tectonic and climatic perturbations: Choshui River, Taiwan, and Typhoon Mindulle (2004)
}

\author{
J. D. MILLIMAN 1 , T.Y LEE ${ }^{2}$, J.C. HUANG ${ }^{3}$ \& S.J. KAO ${ }^{4}$ \\ 1 School of Marine Science, College of William and Mary, Gloucester Point, Virginia, USA \\ milliman@,vims.edu \\ 2 Department of Geography, National Taiwan Normal University, Taipei, Taiwan \\ 3 Department of Geography, Taiwan National University, Taipei, Taiwan \\ 4 State Key Laboratory of Marine Environmental Sciences, Xiamen University, Xiamen, China
}

\begin{abstract}
One reason that small mountainous rivers discharge disproportionately large quantities of sediment to the coastal ocean is because they are particularly susceptible to short-term episodic events, such as earthquakes and floods. The impact of such events, both temporally and spatially, however, has seldom been monitored. Here we report on the results of probably the most thorough monitoring of a flood ever undertaken: the effect of Typhoon Mindulle (2-4 July 2004) on the character of the water transported by the Choshui River, central western Taiwan, during which 74 million tons of sediment were discharged to the adjacent Taiwan Strait. Results from a series of 113 water samples obtained between 2nd and 4th July from five stations along the middle and lower reaches the river indicate that more than half of the suspended sediment was generated in nearby mountains before the river reached its flood plain. While the concentration of dissolved solids remained more or less constant along the mainstem of the river, the composition changed considerably, reflecting the imprints of local geology. An order-of-magnitude downstream increase in $\mathrm{NO}_{3}{ }^{-}$ concentrations reflects the rapid draining of the Tsaoling landslide lake on the Chingshui River, as the 1999 earthquake-generated landslide dam was breached.
\end{abstract}

Key words typhoon; Taiwan; flood; earthquake

\section{INTRODUCTION}

The concentration and magnitude of fluvial sediment discharge to the coastal ocean is controlled by numerous geological and environmental factors, such as drainage basin area, basin relief, source-rock lithology, runoff and human influences (e.g. Ahnert, 1970; Wilson, 1973; Syvitski and Milliman, 2007; Milliman and Farnsworth, 2011). For instance, rivers whose headwaters are in mountainous terrain, particularly small mountainous rivers, tend to have disproportionately greater sediment discharge than larger mountainous rivers or small rivers draining lower elevations or older lithologies (Milliman and Syvitski, 1992; Milliman and Farnsworth, 2011, their Fig. 2.19).

Episodic catastrophic events, such as earthquakes, volcanic eruptions and fires can increase sediment supply, or, in the case of heavy rains and floods, can increase both supply and transport (e.g. Keefer, 1994; Hovius et al., 1997). Smaller rivers are particularly susceptible to such events as their small watersheds are less likely to modulate the impact from such events (Milliman and Farnsworth, 2011, their Fig. 3.45). Hovius et al. (1997) and Dadson et al. (2003, 2004), for example, concluded that earthquake-initiated and typhoon-rain-induced hillslope wasting account for most of the sediment discharged by Taiwanese rivers.

Despite the importance of episodic events on small mountainous rivers, they rarely have been monitored, in part because their occurrence is unpredictable and in part because their monitoring can be both costly and physically dangerous. Prior to the monitoring of the Choshui River (central western Taiwan) during typhoons Mindulle and Aere in 2004, as reported in this paper, we only know of one previous monitoring of a small river during an "event": the thorough monitoring of several southern California rivers in 1969 during two heavy rainstorms (Waanaen, 1969; Warrick and Milliman, 2004).

Our 2004 monitoring, in fact, included five stations along the lower Choshui River watershed during two typhoons - Mindulle (2-7 July) and Aere (24-26 August). These typhoons occurred only 5 years after a major earthquake, Chichi, whose epicentre was in the mid-Choshui basin, thus providing the unique opportunity to quantify the temporal and spatial impacts of both an earthquake and a typhoon. Here we focus our discussion on the impact of Mindulle, a typhoon that 
facilitated several changes in posts-earthquake terrain. A number of previous papers have reported on the effects of typhoon Mindulle on the Choshui River based on data collected at the Chunyun gauging station (Milliman et al., 2007; Goldsmith et al., 2008). Using these data, Hovius et al. (2011) attempted to gauge the sedimentary impact of the Chichi earthquake. This paper, however, is the first that focuses on the complete dataset for the three stations located along the mainstem of the river, as well as some data collected from the Chingshui River tributary.

\section{CHOSHUI RIVER AND THE 1999 (CHICHI) EARTHQUAKE}

Because they are located at the juncture of the Philippine and Eurasian plates, and also lie along what commonly is referred to as "Typhoon Alley", Taiwanese watersheds are susceptible to both earthquakes and typhoon-generated floods. As such, sediment yields of Taiwanese rivers, all of which are $<4000 \mathrm{~km}^{2}$ in area, are amongst the highest in the world. Of the 13 global rivers with calculated sediment yields of $10000 \mathrm{t} / \mathrm{km}^{2} /$ year (the global average is $190 \mathrm{t} / \mathrm{km}^{2} /$ year), eight are Taiwanese (Milliman and Farnsworth, 2011, their Table 2.7). Taiwan's 13 largest rivers, whose collective basin areas sum to $18700 \mathrm{~km}^{2}$, have an average yield $\sim 10000 \mathrm{t} / \mathrm{km}^{2} /$ year, by far the highest of any country in the world. About $75 \%$, often at hyperpycnal concentrations ( $>40 \mathrm{~g} / \mathrm{L})$, of the annual sediment discharge occurs during typhoon-generated floods, which generally account for no more than 3-6 days each year (Kao and Milliman, 2008).

In this paper we focus on the Choshui, third largest river in Taiwan in terms of basin area $\left(3100 \mathrm{~km}^{2}\right)$, second largest in terms of mean annual water discharge $\left(3.6 \mathrm{~km}^{3} /\right.$ year) and first in terms of sediment discharge (40 million tons (Mt) annually) (Kao and Milliman, 2008). It flows from the Central Range (maximum elevation $\sim 3400 \mathrm{~m}$ ) to Taiwan Strait, a distance of $190 \mathrm{~km}$, and is the longest river in Taiwan (Milliman and Farnsworth, 2011) (Fig. 1). Two southern tributaries, the Chingshui River $\left(260 \mathrm{~km}^{2}\right)$ and Chenyuluan River $\left(365 \mathrm{~km}^{2}\right)$ flow into the lower middle part of the Choshui. Both tributaries are about $36 \mathrm{~km}$ long and drain, respectively, the Alishan and Chunda ranges, whose elevations locally exceed $2500 \mathrm{~m}$. The Chingshui River follows the $60-\mathrm{km}$ long Chelungpu Fault (Wu et al., 2007), the epicentre of the 1999 Chichi earthquake. The Choshui River's flood plain, representing the lower $35 \mathrm{~km}$ of the river and occupying $\sim 100 \mathrm{~km}^{2}$ in area, is centre of both agricultural and industrial activity in the Choshui basin; much of the upper part of Choshui's watershed remains relatively unaffected by human activity (Fig. 2).

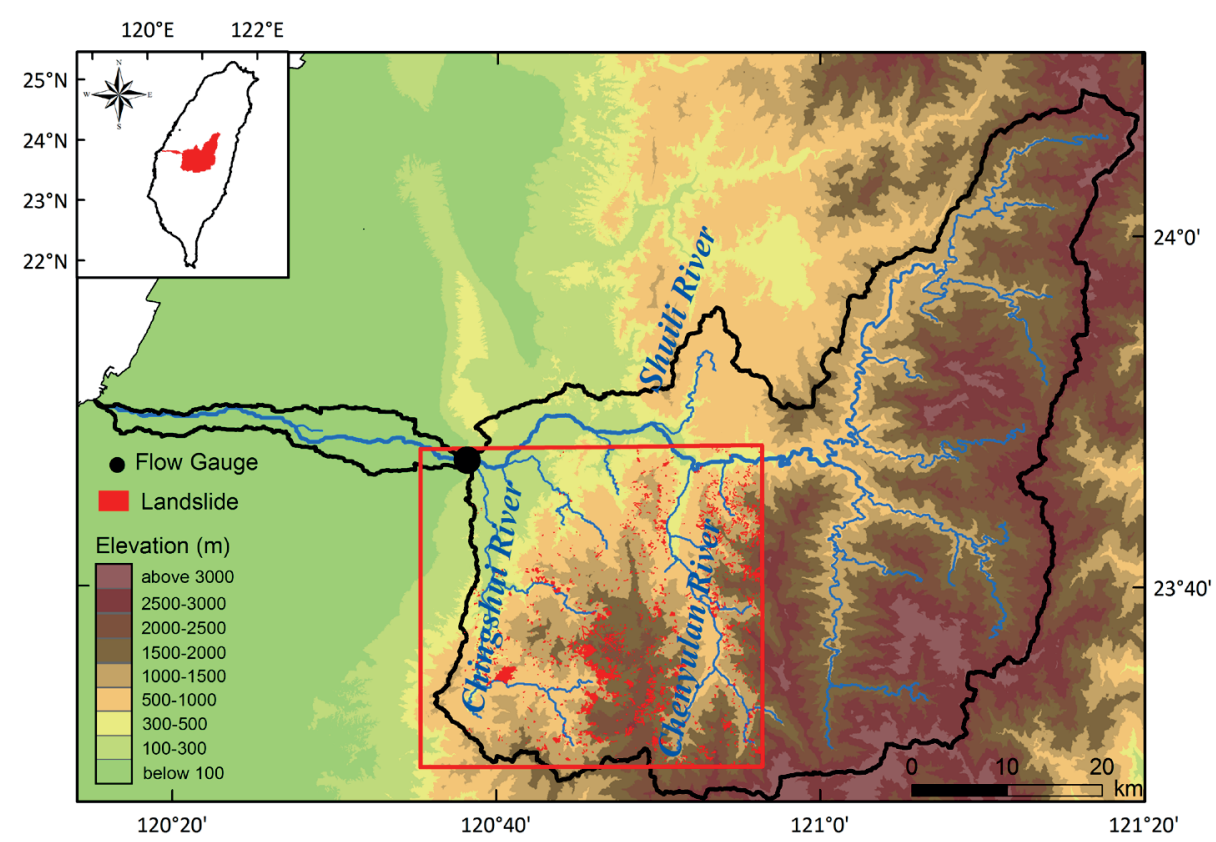

Fig. 1 The Choshui River drainage basin, showing also the Chenyulan and Chingshi tributaries. The small red dots indicate locations of Chichi-generated landslides, primarily in the Chenyulan and Chingshui basins. 


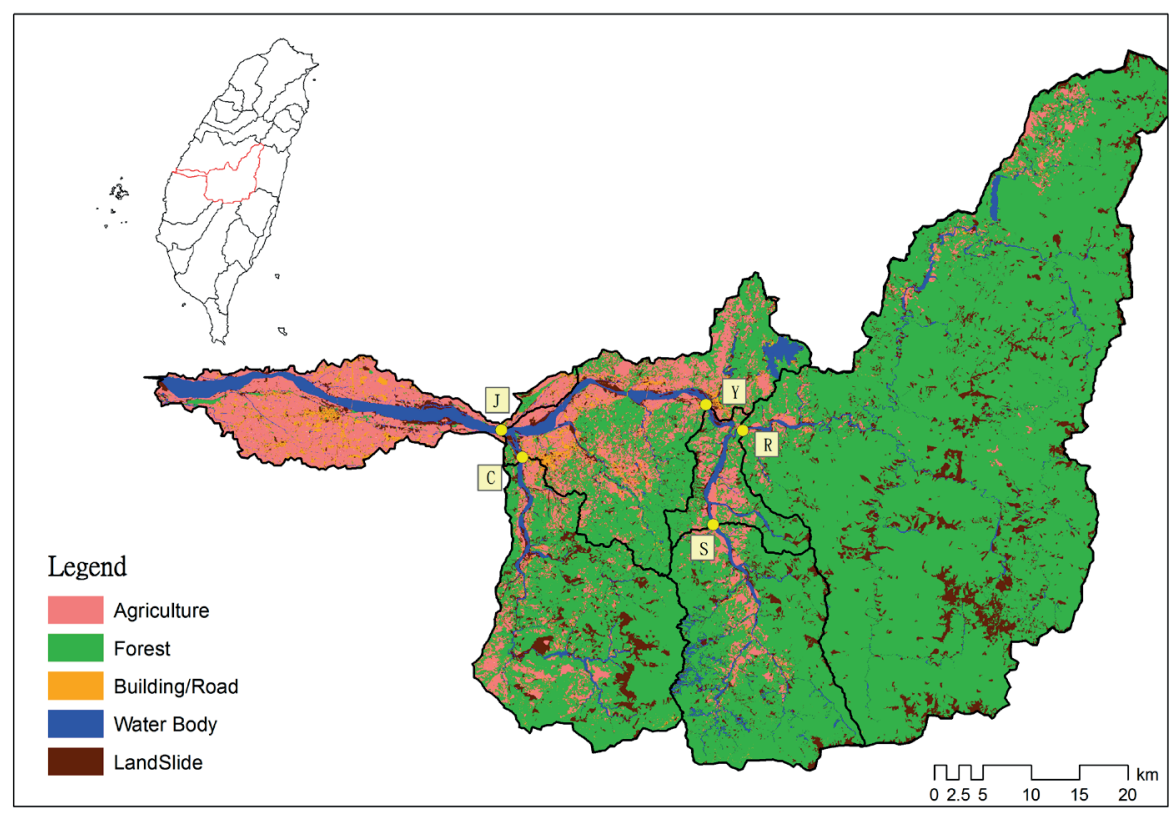

Fig. 2 Land use in the Choshui River watershed. Also shown are the locations of the five watersampling stations (J, Y, R, C, S) occupied during typhoons Mindulle and Aere.

As with other Taiwanese rivers, Choshui River discharge is highly seasonal, about $2 / 3$ of the annual flow occurring between June and September during the SW monsoon. Annual water discharge varies greatly, ranging from $1.1 \mathrm{~km}^{3}$ (1980) to $6.6 \mathrm{~km}^{3}$ (1974), and thus its annual sediment discharge varies widely; between 1965 and 1999 it ranged from $7.6 \mathrm{Mt}$ (1978) to $\sim 120 \mathrm{Mt}$ (1996). According to Kao and Milliman (2008), between 1965 and 2005, more than 40\% of the Choshui River's cumulative sediment load was discharged at hyperpycnal concentrations.

On 21 September 1999, central western Taiwan experienced a Mw 7.6 earthquake, its epicentre being near the city of Chichi, in the middle of the Choshui watershed. Coseismic landslides affected about 3.5\% of the Choshui basin's landscape (Dadson et al., 2004; Chen and Petley, 2005), mostly along the Chenyoulan and Chingshui tributaries, the latter of which lies close to the surface rupture caused by the Chichi earthquake, where an estimated $4-5 \%$ of the basin was impacted by earthquake-generated landslides (Lin et al., 2008). The largest landslide, the Tsaoling landslide, left a $0.4 \mathrm{~km}^{2}$ scar and deposited a sediment volume of $\sim 0.15 \mathrm{~km}^{3}$ over an area $\sim 4 \mathrm{~km}^{2}$ along the Chingshui River valley (Chen et al., 2006, their Fig. 6). This dam created a large lake, appropriately named the Tsaoling landslide lake. When the dam breached on 2 July 2004, during Typhoon Mindulle, the nearly 5-year-old lake emptied quickly (Fig. 3); discharge measured at a neighbouring gauging station increased from $4 \mathrm{~m}^{3} / \mathrm{sec}$ to $>500 \mathrm{~m}^{3} / \mathrm{s}$ in just 5 hours; within another 12 hours, discharge reached and exceeded $1000 \mathrm{~m}^{3} / \mathrm{s}$ before declining rapidly late on 4th July. The sudden release of this impounded water offers an obvious explanation for some of the temporal and spatial variations noted in the water quality (see below).

\section{TYPHOONS: MINDULLE AND AERE}

Between 1990 and 2009, the Choshui River experienced 26 floods whose peak water discharges exceeded $3000 \mathrm{~m}^{3} / \mathrm{s}$, even though there were no major floods in seven of the 20 years. Here we focus on the impact of Typhoon Mindulle, 2-4 July 2004, which locally brought more than $1000 \mathrm{~mm}$ of rainfall, with as much as $90 \mathrm{~mm} / \mathrm{h}$ rainfall measured at the Choshui weather station (Milliman et al., 2007). On 1 July, before Mindulle, river discharge was less than $60 \mathrm{~m}^{3} / \mathrm{s}$, but, in response to typhoon-generated rain, it reached $>400 \mathrm{~m}^{3} / \mathrm{s}$ by midnight and approached $4000 \mathrm{~m}^{3} / \mathrm{s}$ by 07:00 on 3 July. Flow then decreased to $\sim 1000 \mathrm{~m}^{3} / \mathrm{s}$ before a second episode of heavy rain on 4 July again increased discharge to $6600 \mathrm{~m}^{3} / \mathrm{s}$. By that afternoon discharge again declined, 


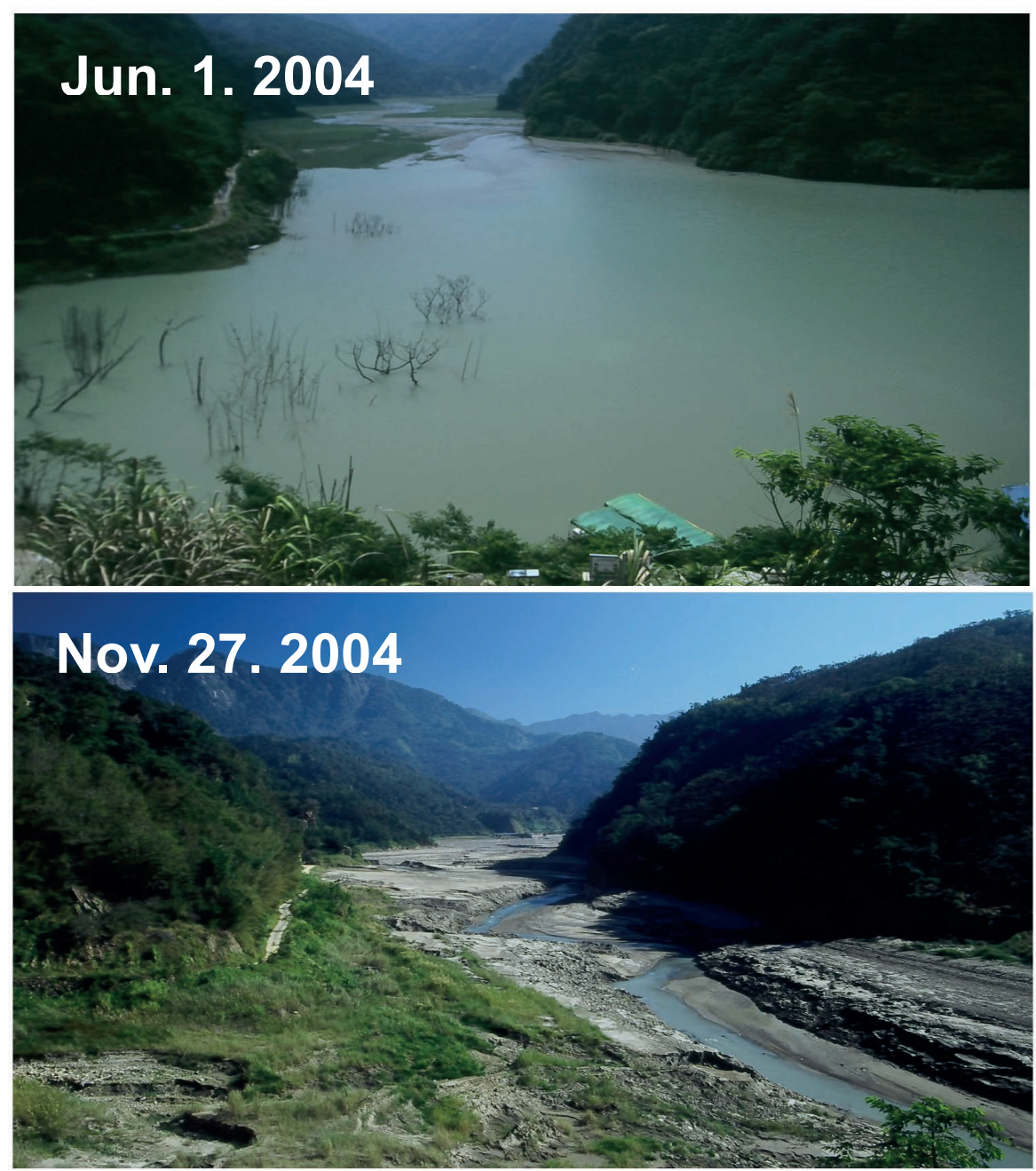

Fig. 3 Tsaoling landslide lake before (1 June 2004) and after (20 July 2004) its breaching and subsequent draining. Breaching occurred early on 2nd June, coincident with the marked increase in Chingshui water discharge and dissolved $\mathrm{NO}_{3}$ levels (see Fig. 14).

although it remained $>1000 \mathrm{~m}^{3} / \mathrm{s}$ until 7th July (Fig. 5). Total volume of water discharge during the Mindulle-generated flood was $0.9 \mathrm{~km}^{3}$.

The second flood that year was generated by Typhoon Aere, which lasted from midday 24 August until midnight 26 August. Its rainfall was considerably less than that during Mindulle, peak rainfall reaching only $40 \mathrm{~mm} / \mathrm{h}$. Total rainfall was less than $200 \mathrm{~mm}$ (Fig. 4), and total water volume discharge was $\sim 0.5 \mathrm{~km}^{3}$; peak discharge $\left(4600 \mathrm{~m}^{3} / \mathrm{s}\right)$ was observed early on 25 August (Fig. 4).

\section{WATER SAMPLING BEFORE, DURING AND AFTER TYPHOONS MINDULLE AND AERE}

Between mid June and early October 2004, one of us (SJK) oversaw the systematic sampling of the Choshui River at five stations along the lower reaches of the watershed; their locations are shown in Fig. 2. Sampling continued until early October. Three stations were located along the mainstem of the river, total distance between the downstream (station $\mathrm{J}$ at the Chunyun Bridge) and the upstream station $(\mathrm{R})$ being $\sim 30 \mathrm{~km}$. The other two stations were located on the Chenyulan and Chingshui tributaries, located respectively between stations R and $\mathrm{Y}$, and $\mathrm{Y}$ and $\mathrm{J}$ (Fig. 2).

Water samples were generally collected at 3-hour intervals during the two typhoons. Between floods, water samples were taken at 2-5 day intervals. Over the $3 \frac{1}{2}$ months, more than 370 series of water samples were taken, 113 during Mindulle alone. Although Mindulle-generated discharge remained high ( $\left.>1000 \mathrm{~m}^{3} / \mathrm{s}\right)$ until 7 th July (Fig. 3), water samples were only taken until about noon 


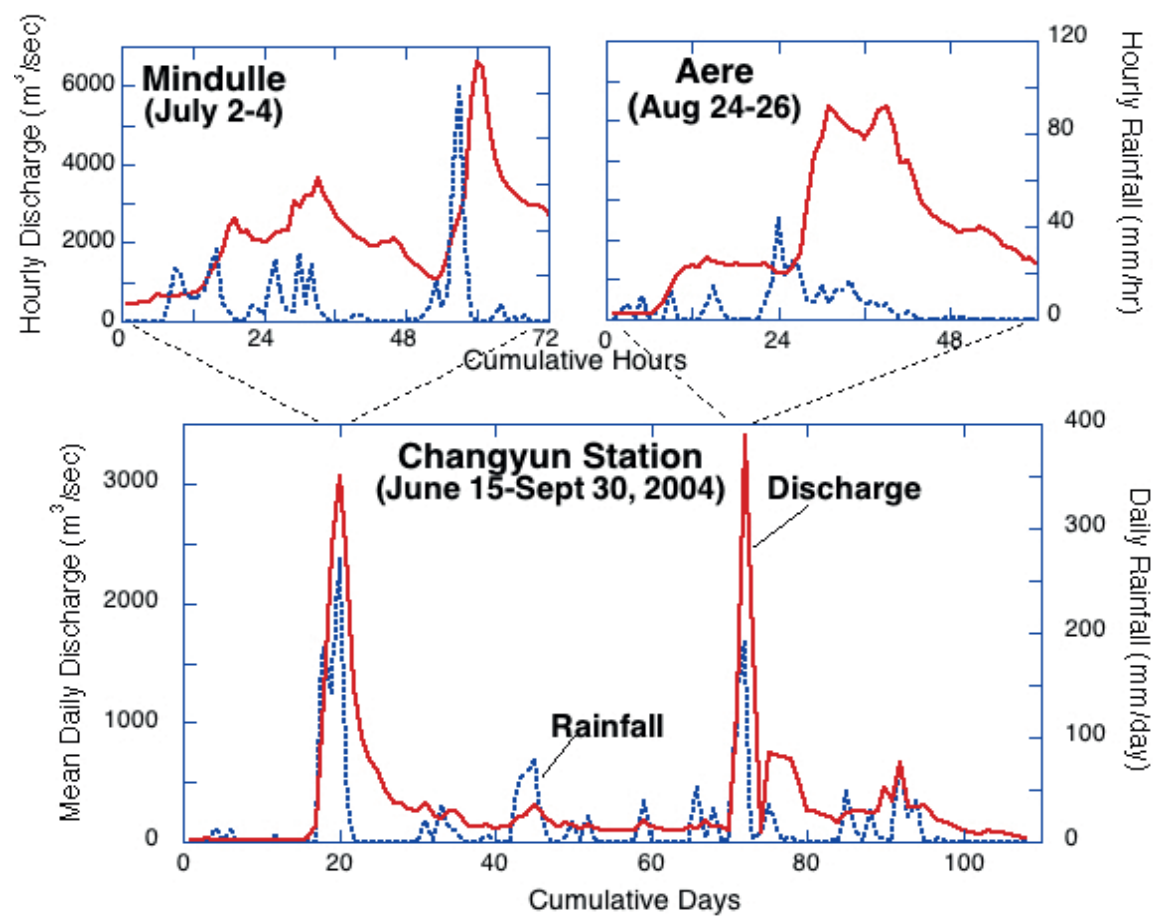

Fig. 4 Rainfall and discharge 15 June-30 September 2004 as measured at the Chichi weather station and Chunyun Bridge, respectively. Mindulle and Aere data are expanded above.

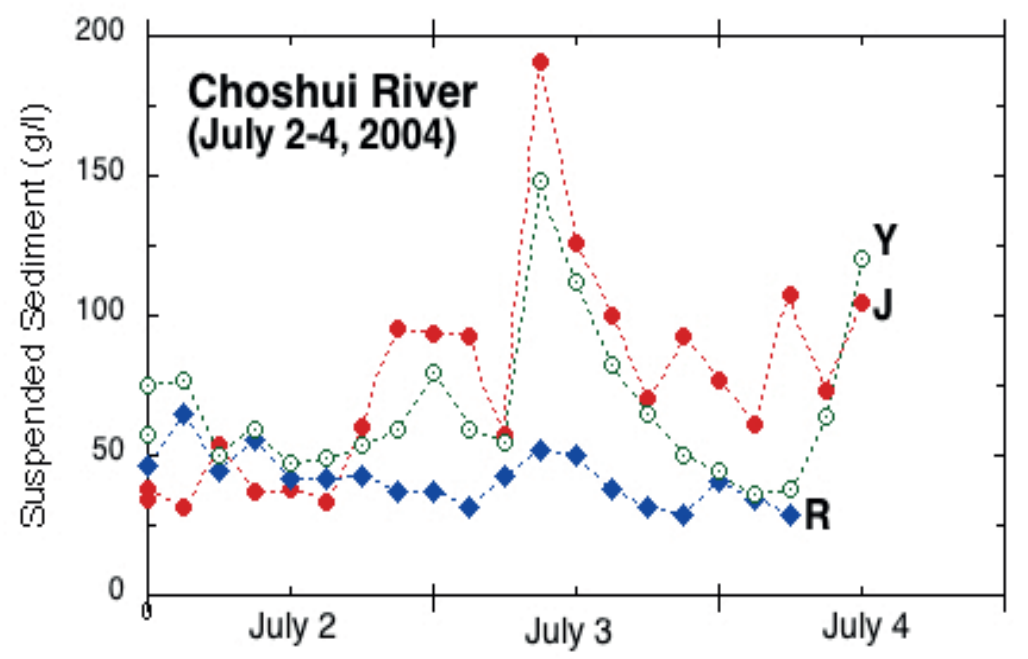

Fig. 5 Suspended sediment concentrations (g/L) at sampling stations J, Y and R during Typhoon Mindulle, 2-4 July 2004.

of the 4th. Typhoon Aere measurements were restricted to Chunyun Bridge and Chinshui River stations; a total of 33 series of water samples were collected.

Depth-integrated water samples were obtained in vertically mounted 1-L low-density polyethylene (LDPE) bottles, which had been previously soaked in deionized water $(18 \mathrm{M})$, that were lowered manually from a bridge. In situ water temperature, $\mathrm{pH}$ and electrical conductivity were measured by using a portable chemistry analyzer (Hanna Instruments). The total suspended matter (TSM) was collected by filtering $>1 \mathrm{~L}$ of sampled water through a pre-weighted and precombusted $0.7 \mu \mathrm{m} \mathrm{GF} / \mathrm{F}$ filter. The mean of the blank, calculated from 10 replicates, was $0.05 \pm 0.01 \mathrm{mg} \mathrm{L}^{-1}$. This blank value was well below the weight of sediment on the filter (generally $>10 \mathrm{~g} / \mathrm{L}$ ). The filtrate was collected in separated polyethylene bottles for anion analysis (quick 
frozen on site in liquid nitrogen and then kept in a freezer for storage) and cation ( $\mathrm{pH}<2$ by $\mathrm{HCl}$ ) analyses. Major anions $\left(\mathrm{NO}_{3}^{-}, \mathrm{F}^{-}, \mathrm{Cl}^{-}\right.$, and $\left.\mathrm{SO}_{4}{ }^{2-}\right)$ were determined using a Dionex ICS-1500 ion chromatography and cations $\left(\mathrm{Na}^{+}, \mathrm{Mg}^{2+}, \mathrm{K}^{+}\right.$, and $\mathrm{Ca}^{2+}$ ) by ICP-MS (Elan 6100, Perkin-ElmerTM Instruments, USA). The analytical details are discussed in greater detail by Goldsmith et al. (2008), Hsu et al. (2010) and Huang et al. (2012). In total, nearly 1500 analyses were obtained from the 113 water samples collected during Typhoon Mindulle, representing by far the most extensive dataset ever analysed from a cataclysmic event.

Although hourly water discharge data were reported by the Water Resources Agency (WRA) from (or near) four of the five sampling stations, their reported discharges are doubtful as the WRA data would suggest that upstream discharges exceed those measured downstream at the Chunyun Bridge gauging station. Here we report only discharge data measured at this downstream station. As such, suspended sediment and dissolved-solid discharges have been calculated only for the Chunyun Bridge station (J) (Figs 7 and 10); for the other stations we report only measured concentrations.

In this preliminary paper we discuss almost only the data collected along the mainstem of the river, that is data from stations $J$ (downstream at the Chunyun Bridge), $Y(\sim 40 \mathrm{~km}$ upstream from $\mathrm{J})$ and $\mathrm{R}(\sim 8 \mathrm{~km}$ upstream from Y) during Typhoon Mindulle. Only briefly do we discuss data gathered at station $\mathrm{C}$ (on the Chinshui River). For brevity - and because only two stations were sampled thoroughly - we do not discuss here the samples taken during Typhoon Aere.

\section{RESULTS}

\section{Suspended sediment}

As seen in Fig. 5, suspended sediment concentrations increased dramatically downstream of station R, where they generally ranged between 40 and $50 \mathrm{~g} / \mathrm{L}$. An abrupt increase is seen at station $\mathrm{Y}$, only $8 \mathrm{~km}$ downstream from $\mathrm{R}$, where concentrations during both flood peaks (mid-day July 3 and July 4) exceeded $100 \mathrm{~g} / \mathrm{L}$. Concentrations were even higher at station J, concentrations on 3rd July reaching $190 \mathrm{~g} / \mathrm{L}$.

Calculating sediment transport requires an accurate sediment rating-curve as well as reliable discharge values. As samples taken at station $\mathrm{R}$ were not near a WRA gauging station and WRA discharge values at station $\mathrm{Y}$ are questionable (see above), we only created rating curves for station J, for both pre- and post-Chichi earthquake, to delineate the relative impacts of the 1999 earthquake and the typhoon. To create a pre-Chichi rating curve, we used the concentrations of 400 suspended sediment samples collected by the WRA between 1987 and 1999 at the Chunyun gauging station (WRA \#1510H057):

$$
Q c=0.0101 \times\left(Q^{1.002}\right) ; \quad \mathrm{R}^{2}=0.58 \text { (Fig. 6) }
$$

where $Q c$ is suspended sediment concentration and $Q$ is instantaneous discharge. If we delete three suspiciously high data points, the pre-Chichi rating curve remains the same but the $\mathrm{R}^{2}$ increases to 0.76 .

If we relied on WRA data alone, deriving a post-Chichi rating curve would be difficult, since between 2000 and 2009 only three suspended sediment $(Q c)$ measurements were taken at discharges greater than $5000 \mathrm{~m}^{3} / \mathrm{s}$, and no $Q c$ measurements were taken during the first three floods immediately following the Chichi earthquake: Bilis (2000), Toraji and Nari (2001). This meagre database can be markedly improved, however, if we include the suspended sediment data that we collected in 2004. Collectively these data show that until 4 July 2004, the sediment rating curve for Chunyun Bridge was considerably elevated relative to the pre-Chichi rating-curve:

$$
Q c=0.00486 \times\left(Q^{1.277}\right) ; \quad \mathrm{R}^{2}=0.84 \text { (Fig. 6) }
$$

Before the earthquake, for example, a discharge of $3000 \mathrm{~m}^{3} / \mathrm{s}$ would have resulted in a suspended sediment concentration of $30 \mathrm{~g} / \mathrm{L}$, whereas after the Chichi earthquake, the concentration is calculated to be $133 \mathrm{~g} / \mathrm{L}$ (Fig. 6), the added $100 \mathrm{~g} / \mathrm{L}$ presumably reflecting sediment eroded from landslide scars and landslide deposits. 


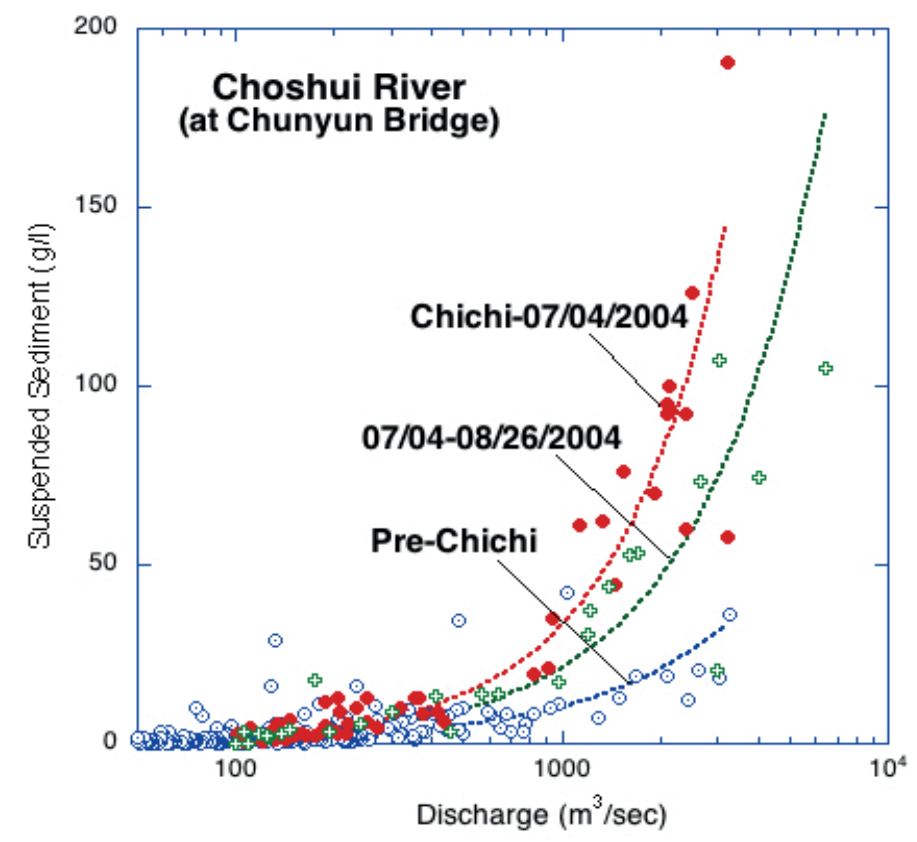

Fig. 6 Pre- and post-Chichi sediment rating curves at Chunyun Bridge (station J). Note both the marked increase in sediment concentrations following the earthquake and the abrupt decrease in concentrations (although still higher than pre-Chichi levels) on 4 July 2004.

This rating curve, however, changed at 09:00 on 4 July 2004, after which a much lower rating curve was derived, one that lasted until the end of Typhoon Aere:

$$
Q c=0.007 \times\left(Q^{1.151}\right) ; \quad \mathrm{R}^{2}=0.75 \text { (Fig. 6) }
$$

We accordingly applied this new rating curve to reported WRA discharges for the latter half of Mindulle as well as to Typhoon Aere discharges.

Using rating curves (2) and (3), total sediment discharge during the Mindulle-generated 2-7 July flood is computed to have been $74 \mathrm{Mt}$, of which $95 \%$ was discharged at hyperpycnal concentrations. Approximately $30 \%$ of the discharged sediment was sand (Milliman et al., 2008) (Fig. 7). Much of the Mindulle sediment flux reflects the elevated sediment yield following the Chichi earthquake. Suspended sediment concentrations, for example, reached $190 \mathrm{~g} / \mathrm{L}$ (water discharge of $2500 \mathrm{~m}^{3} / \mathrm{s}$ ), whereas pre-Chichi $Q c$ at this discharge would have been $\sim 25 \mathrm{~g} / \mathrm{L}$. Using the pre-Chichi rating curve (1) to calculate sediment flux gives a total discharge of $24 \mathrm{Mt}$, meaning that after effects of the Chichi earthquake were responsible for $50 \mathrm{Mt}$ of sediment discharge during

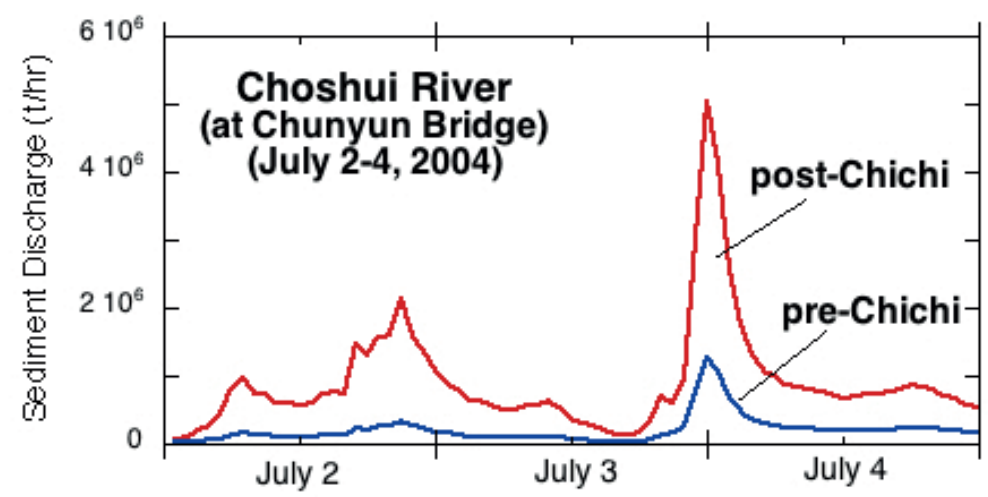

Fig. 7 Calculated sediment discharge past the Chunyun Bridge, July 2-4, 2004. Post-Chichi calculated loads are based on rating curves (2) and (3), whereas the pre-Chichi load was calculated assuming no earthquake, i.e. rating curve (1). The difference between the pre- and post-Chichi curves indicates the amount of discharged sediment generated by the Chichi earthquake, in this case, 50 Mt. 
Mindulle (Fig. 7). Although the earthquake's influence declined considerably after 09:00 on 4 July, it still accounted for 10 of the $25 \mathrm{Mt}$ discharged during Typhoon Aere (unpublished data).

\section{Dissolved solids}

Unlike suspended-sediment concentrations, which varied greatly with both time and location along the Choshui River (Fig. 4), dissolved-solid concentrations were relatively constant at all three stations (Fig. 8). The slightly lower dissolved-solid concentrations at station $\mathrm{J}$ can be explained at least in part by dilution due to higher water discharge (Fig. 9). Using the rating curve shown in Fig. 9 together with WRA hourly discharge values, we calculate that between 2 and 7 July, the Choshui discharged $\sim 0.35 \mathrm{Mt}$ of dissolved solids, about $25 \%$ of the annual average; in contrast, the $74 \mathrm{Mt}$ of sediment discharge represents about twice the annual average load.

Expressed in terms of milliequivalents (meq), $\mathrm{Ca}^{2+}$ generally accounted for $\sim 50 \%$ of the total dissolved cations measured along the Choshui River (particularly at stations $\mathrm{R}$ and $\mathrm{Y}$ ), $\mathrm{Na}$ and $\mathrm{Mg}$ each accounting for $20-25 \%$, and $\mathrm{K}$ for $<10 \%$. Assuming that total dissolved milliequivalents equalled the sum of these four cations, we could then determine the percentage of anions represented by $\mathrm{SO}_{4}{ }^{2-} ; \mathrm{Cl}^{-}$was present in far lower concentrations, leading us to assume that the remainder of the non- $\mathrm{SO}_{4}$ anions was primarily $\mathrm{HCO}_{3}{ }^{-}$.

Dissolved solid composition, however, changed considerably with both time and location, as can be seen in the dissolved $\mathrm{Ca} / \mathrm{Na}$ ratios (Fig. 10), the percentage of dissolved $\mathrm{SO}_{4}{ }^{2-}$ (Fig. 11), and nitrate concentration (Fig. 13). Dissolved solids at station R were dominated by calcium; during much of $2 \mathrm{July}$, the $\mathrm{Ca} / \mathrm{Na}$ ratios were greater than 12 , then gradually declined to $\sim 8$. $\mathrm{Ca} / \mathrm{Na}$ ratios measured at station $\mathrm{Y}$ also declined with time being slightly lower than those seen at station $\mathrm{R}$, although still greater than $\sim 7$. In contrast, $\mathrm{Ca} / \mathrm{Na}$ ratios at station $\mathrm{J}$ (Chunyun Bridge) declined sharply as the flood began, and for most of the period were less than 3 (Fig. 11). Dissolved $\mathrm{SO}_{4}{ }^{2-}$ concentrations (reported as \% total anions in meq) were similar at stations $\mathrm{R}$ and $\mathrm{Y}$, remaining slightly greater than $50 \%$ in the early stages of the flood, then decreasing to less than $50 \%$ in the later stages. $\mathrm{SO}_{4}{ }^{2-}$ concentrations at $\mathrm{J}$, in contrast, were $>70 \%$ of the total anions during early stages of the flood, then declined to less than 50\% toward the end of the sampling period (Fig. 12).

Probably the most dramatic change seen in the Choshui River during the Mindulle-generated flood was $\mathrm{NO}_{3}{ }^{-}$concentrations, as seen in Fig 13. Nitrate levels measured at stations $\mathrm{R}$ and $\mathrm{Y}$ gradually increased from $<1 \mathrm{ppm}$ early on 1 July to $\sim 4 \mathrm{ppm}$ on 4 July. Far more impressive was the sudden increase in $\mathrm{NO}_{3}{ }^{-}$in station $\mathrm{J}$ waters; early on the 2nd concentrations were similar to those at R and Y. i.e. about $1 \mathrm{ppm}$. By early on the 3rd, however, levels had climbed to $7 \mathrm{ppm}$, and on the 4th they approached 10 ppm (Fig. 13).

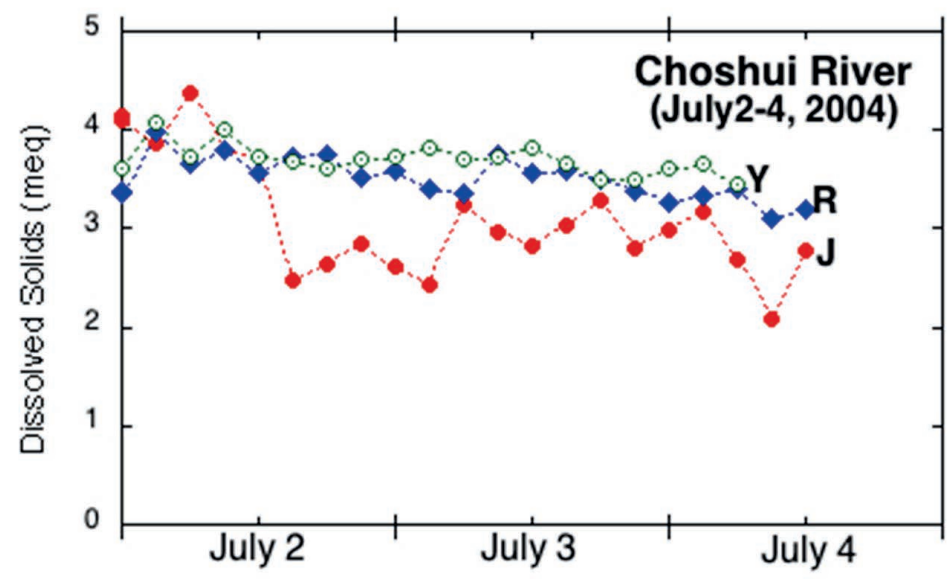

Fig. 8 Measured total dissolved solids, reported in milliequivalents (meq). In contrast to the suspended sediments (Fig. 5), station $\mathrm{R}$ has roughly similar dissolved solid concentrations to those measured at station S. The lower concentrations noted at station $\mathrm{J}$ can be explained in part by higher discharge at this downstream station. 


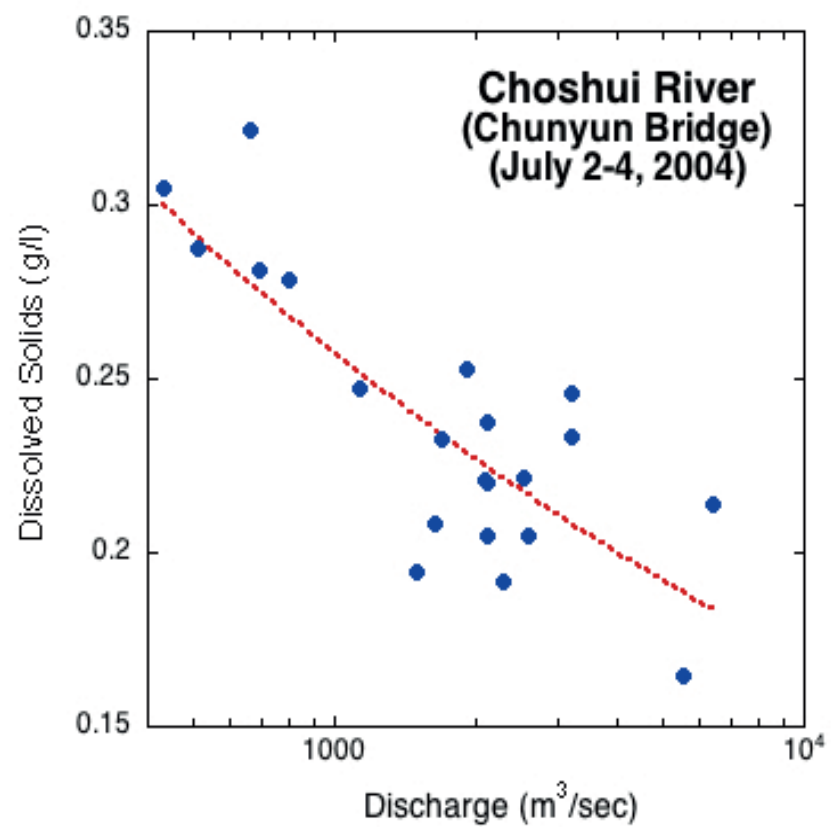

Fig. 9 Dissolved solids (expressed in meq) versus reported water discharge at the Chunyun Bridge (station J), 2-4 July 2004.

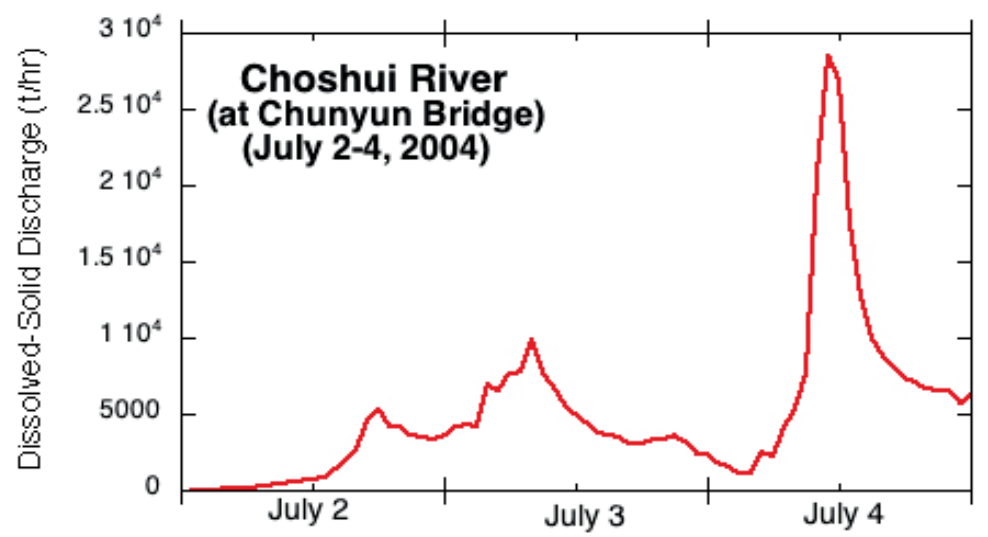

Fig. 10 Calculated dissolved-solid discharge past the Chunyun Bridge, 2-4 July 2004.

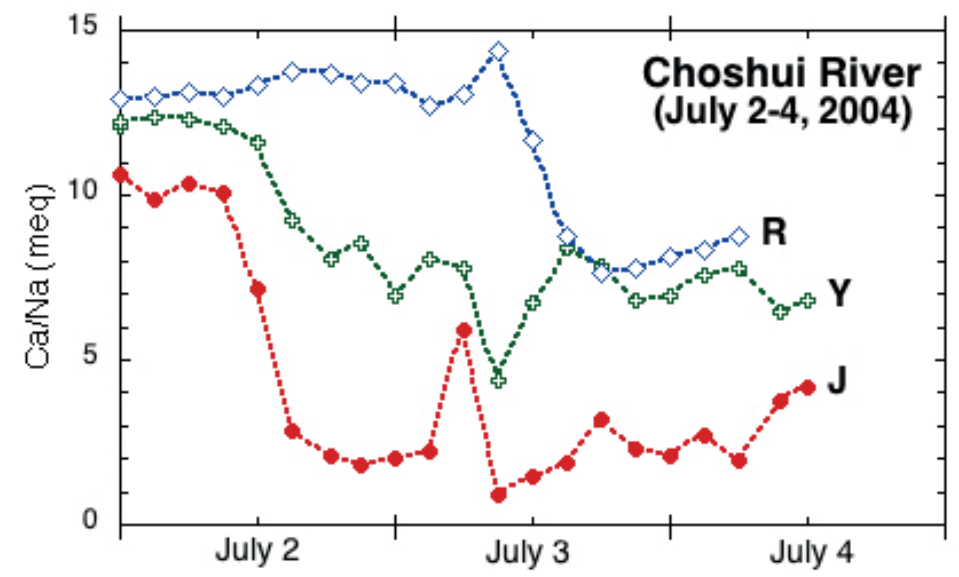

Fig. 11 Temporal and spatial variations in $\mathrm{Mg} / \mathrm{Na}$ ratios (in meq) at Choshui River stations $\mathrm{R}, \mathrm{Y}$ and $\mathrm{J}$, 2-4 July 2004. 


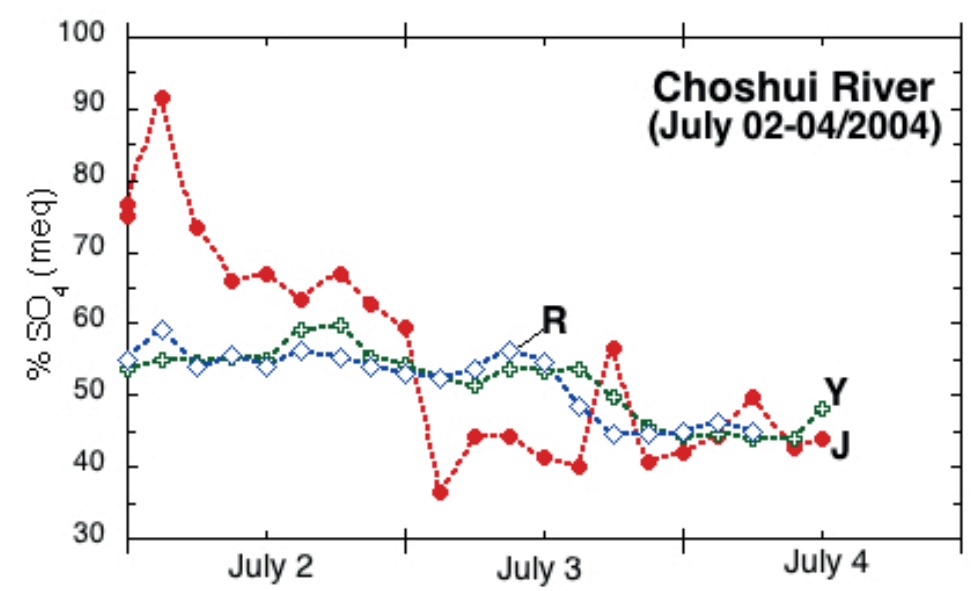

Fig. 12 Temporal and spatial variations of $\mathrm{S}_{4}$ relative to total anions (meq) at Choshui River stations R, Y and J, 2-4 July 2004.

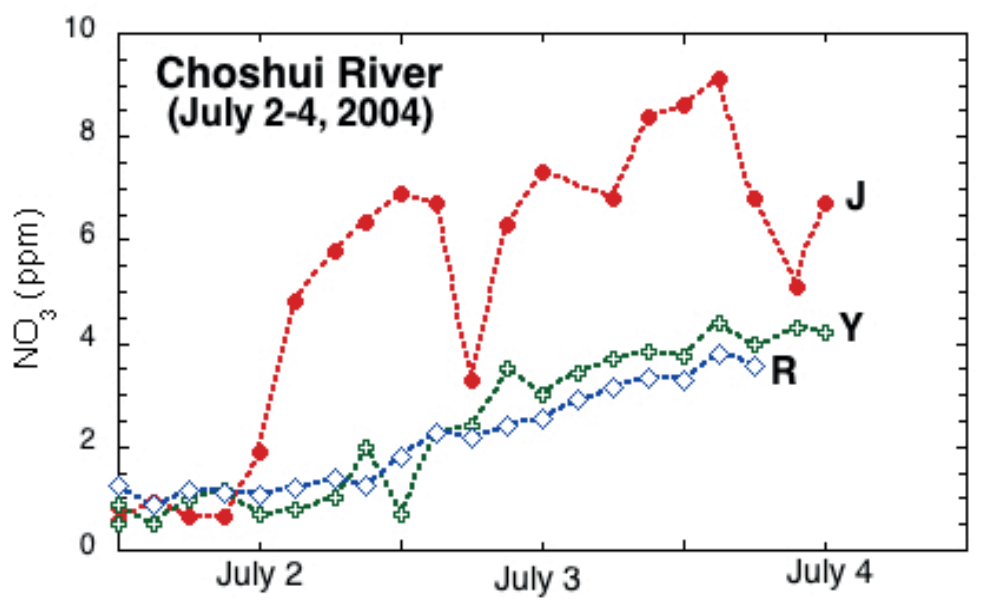

Fig. 13 Temporal and spatial variations in dissolved nitrate at Choshui River stations R, Y and J, 2-4 July 2004. Note the 8-fold increase in $\mathrm{NO}_{3}{ }^{-}$at station $\mathrm{J}$ on 2 July.

\section{DISCUSSION AND CONCLUDING REMARKS}

Other than the similar suspended sediment concentrations noted at J and Y (Fig. 4) and similar dissolved-solid concentrations (Fig. 8), water samples collected at station $\mathrm{J}$ tended to have distinctly different values to those measured at either R or Y, which often had somewhat similar values. Most apparent were the differences in dissolved-solid composition. Water passing station $\mathrm{J}$ had much higher Na concentrations, as evidenced by distinctly lower $\mathrm{Ca} / \mathrm{Na}$ ratios (Fig. 11), lower $\mathrm{SO}_{4}{ }^{2-}$ concentrations (Fig. 12), suggesting higher $\mathrm{HCO}_{3}{ }^{-}$levels, and dramatically higher $\mathrm{NO}_{3}{ }^{-}$ concentrations, often 2 to 3 times higher than those measured at stations R or Y (Fig. 13). In searching for the source of this change in dissolved-solids composition, the most obvious place to look is at the Chingshui River, which enters the Choshui mainstem between stations Y and J (see Fig. 2). Sampling station $\mathrm{C}$ on the Chingshui's shows lower $\mathrm{Ca}^{+2}$ and higher $\mathrm{Na}$ concentrations (Fig. 14) than those in the upstream portions of the Choshui (as measured at stations R and Y). Although not shown here, Chingshui waters also have lower $\mathrm{SO}_{4=}$ concentrations, which probably explain the decrease (with time) in $\mathrm{SO}_{4}=$ concentrations at station J. Discharge from the Chingshui thus explains the marked changes noted in both $\mathrm{Ca} / \mathrm{Na}$ and $\mathrm{SO}_{4=}$ noted at station $\mathrm{J}$.

The marked increase in $\mathrm{NO}_{3}$ - at station $\mathrm{J}$ appears to be the direct result of the discharge of very high $\mathrm{NO}_{3 \text { - }}$ concentrations (up to $15 \mathrm{ppm}$ ) by the Chingshui (Fig. 13). The marked increase in both Chingshui water discharge (noted above) and $\mathrm{NO}_{3}$ - concentrations occurred in the early morning of 


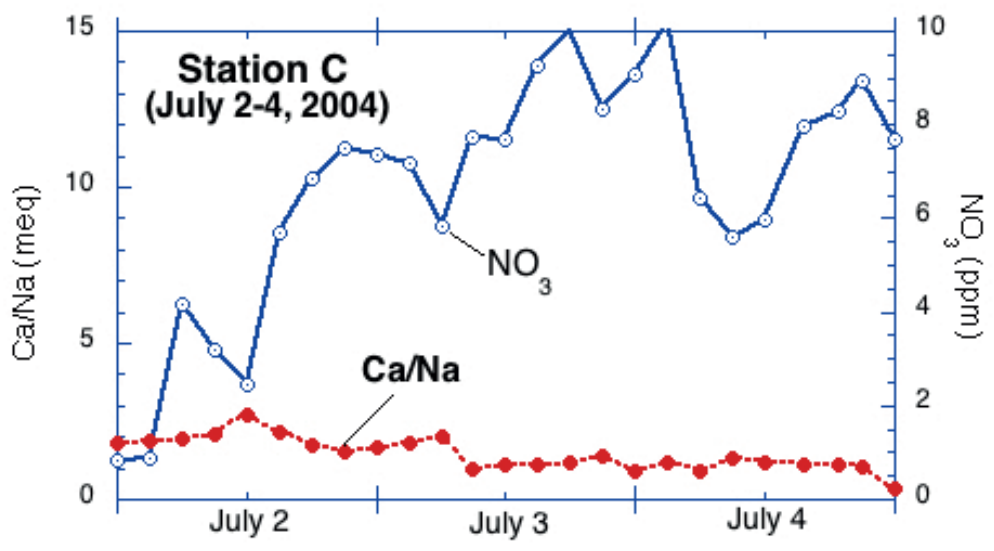

Fig. 14 Temporal variations in $\mathrm{Ca} / \mathrm{Na}$ ratios (meq) and dissolved nitrate at station $\mathrm{C}$ on the Chingshui River, 2-4 July 2004. Note the order-of-magnitude increase in dissolved nitrate on early 2nd July.

2nd July, coincident with the breaching of the Tsaoling landslide lake (see Fig. 3). Presumably the high nitrogen levels in the lake waters reflects application of fertilizer to the tea plantations located in the neighbouring hills.

Further study of our extensive database undoubtedly will show us more temporal and spatial variations in the suspended sediment and dissolved-solid discharges during both Mindulle and Aere, which, in turn, can help us further understand in a quantitative sense the impact of episodic events on the discharge from small mountainous rivers.

\section{REFERENCES}

Ahnert, F. (1970) Functional relationships between denudation, relief, and uplift in large mid-latitude drainage basins: Am. Jour. Sci. 268, 243-263.

Chen, R.-F., et al. (2006) Topographical changes revealed by high-resolution airborne LiDAR data: The 1999 Tsaoling landslide induced by the Chi-Chi earthquake. Eng. Geol. 88, 160-172.

Chen, H. and Petley, D.N. (2005) The impact of landslides and debris flows triggered by typhoon Mindulle in Taiwan. Quart. Jour. Eng. Geol. Hydrogeol. 38, 301-304.

Dadson, S.J., et al. (2003) Links between erosion, runoff variability and seismicity in the Taiwan orogeny. Nature 426, 648-651.

Dadson S.J., et al. (2004) Earthquake-triggered increase in sediment delivery from an active mountain belt. Geology 32, 733-736.

Goldsmith, S.T., et al. (2008) Extreme storm events, landscape denudation, and carbon sequestration: Typhoon Mindulle, Choshui River, Taiwan. Geology 36, 483-486.

Hsu, S.C., et al. (2010) Effects of acidic processing, transport history, and dust and sea salt loadings on the dissolution of iron from Asian dust. Journal of Geophysical Research-Atmospheres, 115, doi:10.1029/2009JD013442.

Huang, J.C., et al. (2012) Land use effect and hydrological control on nitrate yield in subtropical mountainous watersheds. Hydrology and Earth Systems Science 16, 699-714.

Keefer, D.K. (2004) Investigating landslides caused by earthquakes - A historical review. Surveys in Geophysics 23, 473-510.

Hovius, N., et al. (2011) Prolonged seismically induced erosion and the mass balance of a large earthquake. Earth and Planetary Science Letters 304, 347-355.

Hovius, N., Stark, C.P. and Allen, P.A. (1997) Sediment flux from a mountain belt derived by landslide mapping. Geology 25, $231-234$.

Kao, S.J. and Milliman, J.D. (2008) Water and sediment discharge from small mountainous rivers, Taiwan: The roles of lithology, episodic events, and human activities. Journal of Geology 116, 431-448.

Milliman, J.D. and Farnsworth, K.L. (2011) River Discharge to the Coastal Ocean: A Global Synthesis. Cambridge University Press, $384 \mathrm{p}$.

Milliman, J.D. and Syvitski, J.P.M. (1992) Geomorphic/tectonic control of sediment discharge to the ocean: The importance of small mountainous rivers. Journal of Geology 100, 525-544.

Milliman, J.D., et al. (2007) Short-term changes in seafloor character due to flood-derived hyperpycnal discharge: Typhoon Mindulle, Taiwan, July 2004. Geology 35, 779-782.

Syvitski, J.P.M. and Milliman, J.D. (2007) Geology, Geography, and Humans battle for dominance over the delivery of fluvial sediment to the coastal ocean. Journal of Geology 115, 1-19.

Waananen, A. O. (1969) Floods of January and February 1969 in central and southern California. US Geol. Survey. Open File Report, 223.

Warrick, J.A. \& Milliman, J.D. (2003) Hyperpycnal sediment discharge from semiarid southern California rivers: Implications for coastal sediment budgets. Geology 31, 781-784. 